\title{
Mineral and Sea-Salt Aerosol Fluxes over the Last 340 kyr Reconstructed from the Total Concentration of Al and Na in the Dome Fuji Ice Core
}

\author{
Hironori Sato $^{1}$, Toshitaka Suzuki ${ }^{1}$, Motohiro Hirabayashi ${ }^{2}$, Yoshinori Iizuka ${ }^{3}$, \\ Hideaki Motoyama ${ }^{2}$, Yoshiyuki Fujii' \\ ${ }^{1}$ Department of Earth and Environmental Sciences, Faculty of Science, Yamagata University, Yamagata, Japan \\ ${ }^{2}$ National Institute of Polar Research, Tokyo, Japan \\ ${ }^{3}$ Institute of Low Temperature Science, Hokkaido University, Sapporo, Japan \\ Email: s12e103d@st.yamagata-u.ac.jp
}

Received December 22, 2012; revised January 24, 2013; accepted February 1, 2013

Copyright (C) 2013 Hironori Sato et al. This is an open access article distributed under the Creative Commons Attribution License, which permits unrestricted use, distribution, and reproduction in any medium, provided the original work is properly cited.

\begin{abstract}
A quantitative analysis of the total concentrations of $\mathrm{Al}$ and $\mathrm{Na}$ in the Antarctic ice sheet during the past 340 kyr was performed by applying the acid digestion method to the Dome Fuji ice core. Atmospheric fluxes of mineral and sea-salt aerosol to Dome Fuji were calculated from the total concentration. The average fluxes of mineral aerosol to Dome Fuji in the periods of glacial maximum, $18.6 \pm 10.1 \mathrm{mg} \cdot \mathrm{m}^{-2} \cdot \mathrm{yr}^{-1}$, were larger than the value in the interglacial periods, 3.77 $\pm 2.20 \mathrm{mg} \cdot \mathrm{m}^{-2} \cdot \mathrm{yr}^{-1}$. Conversely, the fluxes of sea-salt have no significant difference between the average value of glacial maximum, $130 \pm 55 \mathrm{mg} \cdot \mathrm{m}^{-2} \cdot \mathrm{yr}^{-1}$, and that of interglacial, $111 \pm 54 \mathrm{mg} \cdot \mathrm{m}^{-2} \cdot \mathrm{yr}^{-1}$. The results obtained in this study suggest that the variation of mineral aerosol flux in Dome Fuji, together with climate change, was much larger than that of sea-salt aerosol flux. This result may have occurred because the variety in the intensity of the source and transport during the glacial-interglacial cycle is more significant for mineral aerosol than that for sea-salt aerosol.
\end{abstract}

Keywords: Ice Core; Antarctica; Dome Fuji; Climate Change; Aerosol Flux; Full Digestion

\section{Introduction}

Atmospheric aerosols have controlled the energy balance of the Earth through radiative forcing [1,2]. Moreover, their chemical properties have contributed to changes in the climate and environment of the Earth. For example, chemical species in aerosols play an important role in the $\mathrm{CO}_{2}$ absorption mechanism of the ocean accompanying climate changes. The iron hypothesis, proposed by Martin [3], states that the iron contained in aerosols activated the biological pump in the glacial period. Oba and Pedersen considered that the $\mathrm{CaCO}_{3}$ contained in mineral aerosols was supplied to and dissolved in the ocean to activate the alkalinity pump in the glacial ocean [4]. Changes in the environment of the Earth's surface accompanying a climate change would modify the generation, transport, and the removal processes of mineral and sea-salt aerosols. Modification of aerosol circulation as a result of environmental change further accelerates climate change through the feedback power of atmospheric aerosols. To quantitatively clarify the role of aerosols in past climate changes, analyses of mineral and sea-salt particles in ice cores obtained in the Arctic and Antarctic were performed [5]. Measurement of the metallic components in ice cores is a useful method for quantitative analysis of the particulate matter in these cores. Previous studies include continuous flow analysis (CFA) of the dissolved ionic metals in melted ice cores [6,7], particle induced X-ray emission (PIXE) measurement of metals in the particles collected from ice cores by filtration $[8,9]$, and inductively coupled plasma-sector field mass spectrometry ICP-SFMS measurement of acid leachable iron [10]. It is expected that a large portion of the metallic components contained in snow and ice sheets in Antarctica exist as insoluble particulates. It is well known that nearly all $\mathrm{Al}$ and $\mathrm{Fe}$ in these mineral particles exist as insoluble aluminosilicates in snow and rain [11,12]. Several recent studies that discuss metallic elements in ice cores also report the significance of insoluble metal in the cores $[6,10,13]$. Therefore, analysis of the ionic species only is insufficient using ice cores to reconstruct aerosol climate changes. 
It is very difficult to collect very small amounts of insoluble particles in an ice core without loss by using a filtration method. In addition, such filtration methods cannot distinguish metallic components originally supplied to the ice sheet as particles that have melted at the time of core melting. Analysis of acid leachable metal is generally recommended, but some minerals continue to release metals into the solution over several weeks [14]. In order to solve such problems, full-digestion analysis of particulate matter in ice cores by using acid and a hightemperature and pressure bomb is effective. While the particulate matter in the ice melt solution and on the filter are inhomogeneous, metallic components in the sample solution prepared by acid full-digestion is completely homogenous. Thus, full-digestion analysis provides accurate and representative data for the total (dissolved + particulate) concentration of metals in ice cores. Few examples of metal analysis in ice cores that apply the fulldigestion method have been reported. Gaspari et al. obtained only 16 data of the total concentration of iron in the Dome $\mathrm{C}$ ice core by using acid-assisted microwave digestion and reported that the results of acid leachable iron occupied only $30 \%-40 \%$ of the total iron during the Holocene [10].

In this study, we measured the total concentration of metallic elements by applying a full-digestion analysis to the ice core obtained from Dome Fuji, Antarctica. Such data of total concentration of metals have not been systematically obtained in previous ice core studies. Our results enable quantitative analysis of the role of mineral and sea-salt aerosol in climate change. The Japanese Antarctic Research Expedition conducted deep ice sheet drillling at Dome Fuji $\left(77^{\circ} 19^{\prime} \mathrm{S}, 39^{\circ} 42^{\prime} \mathrm{E}\right.$; 3810 ma.s.l) at the peak of the east Dronning Maud Land, Antarcticain 1996 and succeeded in collecting a $2503 \mathrm{~m}$ ice core, known as the first Dome Fuji ice core (DF1 core) [15]. Watanabe et al. determined that the profile of oxygen isotope ratio recorded in theDF1 and the Vostok ice core have good agreement over the past three glacial cycles, concluding that the climate change occurring in East Antarctica may be essentially homogeneous [16]. Kawamura et al. performed an analysis of the $\mathrm{O}_{2} / \mathrm{N}_{2}$ ratio in air trapped in the DF1 core to clarify that the ice core covered the last 340 kyr of climate change and that the climatic record in the core supports the Milankovitch theory [17]. In addition, analysis of the concentration of soluble ion species [18], the volcanic layers [19], the number of microparticles [20], and the chemical composition of salt particles in the DF1 core [21-23] was conducted for clarifying changes in the Earth's climate and environment. In this study, we measured the total concentration of $\mathrm{Al}$ and $\mathrm{Na}$ in the DF1 core, and we present the record of atmospheric fluxes of mineral and sea-salt aerosols occurring over the past 340 kyr.

\section{Experimental}

Anice block with a thickness of $7 \mathrm{~cm}$ was cut from the entire layer of the DF1 core. To remove contamination on the surface of the ice block, a thickness of approximately $5 \mathrm{~mm}$ was sliced from the surface with a ceramic knife. The ice block was then placed in a polyethylene container and rinsed with approximately $1 \mathrm{ml}$ of ultrapure water from a wash bottle. The solution in the container was discarded by decantation. This washing procedure was repeated three times. Next, the ice block was placed at room temperature until $10 \mathrm{ml}$ of the ice melted. The melted water was discarded, and the same washing procedure was repeated again three times. The ice block was then entirely melted within the polyethylene container, and the solution was adjusted to $0.1 \mathrm{~N}-\mathrm{HNO}_{3}$. The solution was entirely evaporated in a Teflon vessel, and the residue was decomposed by the microwave acid digestion method with $0.3 \mathrm{ml}$ of concentrated $\mathrm{HNO}_{3}$ and $0.2 \mathrm{ml}$ of concentrated HF [24]. The microwave decomposition vessel Type P-25 (San-ai Kagaku) was used in this study. The concentrations of $\mathrm{Al}$ and $\mathrm{Na}$ in the solution were measured by Inductively Coupled Plasma Mass Spectrometry (Hewlett Packard, HP4500) with a desolvating nebulizer system (CETAC, Aridus). The multi-element solution XSTC-13 (SPEX CertiPrep) was used as a standard for the analysis. In addition, ultrapure water produced by Direct-Q (Millipore) and an ultrapure reagent produced by Kanto Chemical Co. were used in the experiment. All apparatus were soaked in a $1 \mathrm{~N}-\mathrm{HNO}_{3}$ solution for more than three days to remove metal contamination before being used in the experiment. All experiments were performed within a Class 100 laminar flow clean bench.

\section{Results and Discussion}

Profiles of the concentration of total $\mathrm{Al}(\mathrm{t}-\mathrm{Al})$ and total $\mathrm{Na}(\mathrm{t}-\mathrm{Na})$ of the DF1 core for the past $340 \mathrm{kyr}$ are shown in Figure 1 together with the profile of $\delta^{18} \mathrm{O}$ [17]. We can consider that $\mathrm{t}-\mathrm{Al}$ is a proxy of mineral particles in the ice core; however, we must be aware that $\mathrm{t}-\mathrm{Na}$ is derived from sea-salt in addition to mineral particles. The concentrations of $\mathrm{t}-\mathrm{Al}$ in the DF1 core ranged from 1.14 $\mathrm{mg} \cdot \mathrm{kg}^{-1}$ to $262 \mathrm{mg} \cdot \mathrm{kg}^{-1}$, and the maximum concentration was approximately 230 times the value of the minimum concentration. The concentration peaks of $\mathrm{t}-\mathrm{Al}$ appeared in the periods of glacial maximum at the past three glacial epochs. In periods other than glacial maximum, particularly the interglacial period, t-Al concentration showed a lower value. This variation qualitatively coincides with the results of the terrigenous metals in the ice cores from Vostok [25] and Dome C [6-10]. It is well known that the arid areas on the continents expanded, and the frequency of dust storms and the activity of meridional 

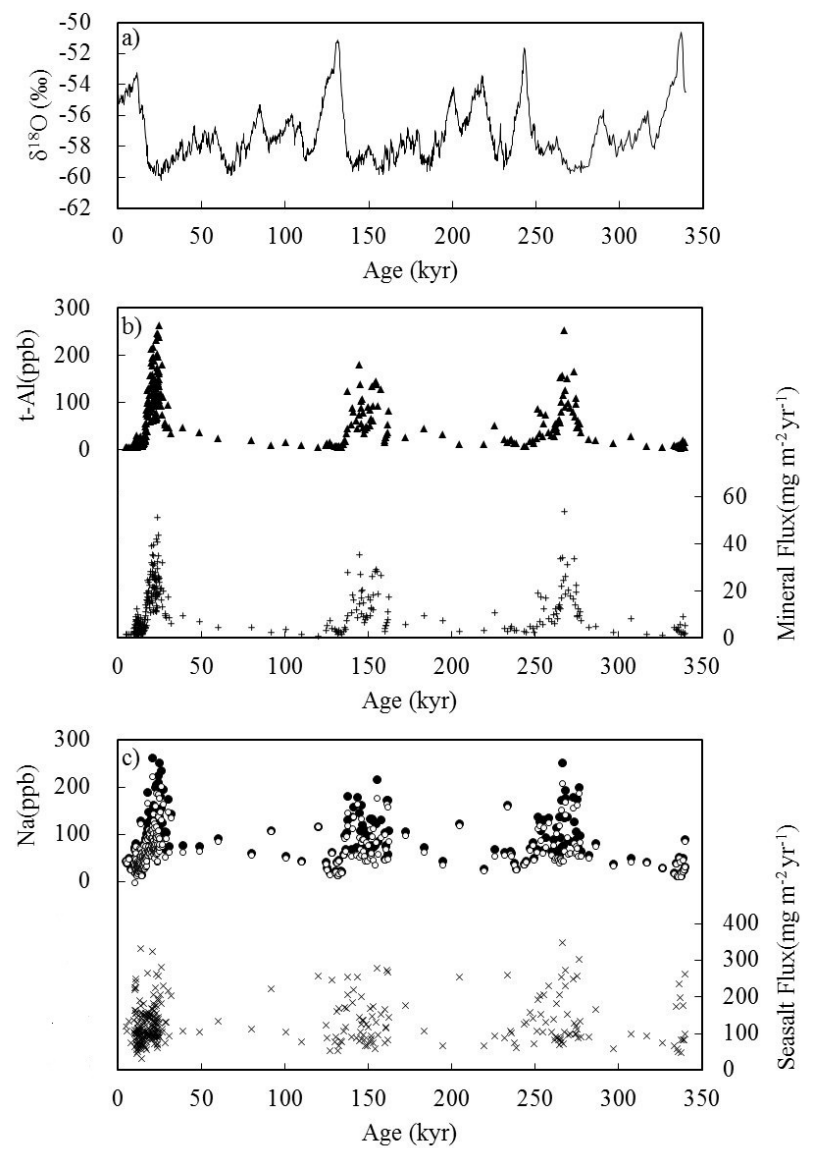

Figure 1. Profiles of (a) $\delta^{18} \mathrm{O}$ (Kawamura et al., 2007); (b) t-Al concentration (closed triangles) and mineral flux (plus signs); and (c) t-Na concentration (closed circles), sea-saltNa concentration (open circles) and sea-salt flux (crosses) of the Dome Fuji ice core during the past 340 kyr.

circulation increased during the Last Glacial Maximum (LGM) [26]. A considerable amount of evidence implies that the atmosphere of the glacial period was generally dustier than that of present conditions [25,27-31]. The record of t-Al concentration in the DF1 core obtained in this study also supports this climate scenario. The maximum concentration of t-Al obtained in this study, 262 $\mathrm{mg} \cdot \mathrm{kg}^{-1}$, was twice that of the maximum concentration of $\mathrm{Al}$, approximately $130 \mathrm{mg} \cdot \mathrm{kg}^{-1}$, in the Vostok core obtained through Instrumental Neutron Activation Analysis of a vigorously shake nice melt solution [25]. We suppose that shaking may not produce sufficiently homogenous particulate matter in the solution for effective chemical analysis of the metal. The difference in the maximum concentration of $\mathrm{Al}$ may be due to the difference in parameters such as sample depth, coring site, and analytical method. Although we cannot entirely explain which reason is principal, we expected that the difference in the depth of the sample cutting or analytical method may be more significant than spacial variability. The average t$\mathrm{Al}$ concentration and its standard deviation (1 s) during 5 -
$15 \mathrm{kyr}$, roughly corresponding to the Holocene (HOL), was $10.9 \pm 6.01 \mathrm{mg} \cdot \mathrm{kg}^{-1}$, and that during $15-30 \mathrm{kyr}$, roughly corresponding to the LGM, was $106 \pm 57$ $\mathrm{mg} \cdot \mathrm{kg}^{-1}$. Therefore, the LGM/HOL ratio of the average concentration of t-Al was approximately 10 . The LGM/ HOL ratio of mass concentration of micro-particles obtained by the particle counter was reported as 11 in the DF1 [19]. The LGM/HOL ratio of the t-Al concentration agreed with that of the micro-particle concentration, which reflects the extent of LGM-HOL changes in mineral aerosol deposition. Marino et al. [9] measured the concentration of Ti contained in the Dome $\mathrm{C}$ ice core, in which the stable and insoluble crustal marker was the same as that of Al. The LGM/HOL ratio for Ti concentration calculated from their results was 14 , which was also comparable to the results oft-Al concentration analysis obtained in this study. In particular, the results indicate that the mineral aerosol comprising the $\mathrm{t}-\mathrm{Al}$ concentration in the ice sheet of Dome Fuji increased by approximately ten times and was deposited in LGM in which the cold and dry climate reached its peak. In the Holocene, the warm and wet climate progressed. Glacial-interglacial variations of mineral and sea-salt aerosol fluxes are discussed subsequently.

The range of t-Na concentration in the DF1 was 11.8 $262 \mathrm{mg} \cdot \mathrm{kg}^{-1}$. Although concentration peaks observed in the periods of glacial maximum were the same as those of $\mathrm{t}-\mathrm{Al}$, the ratio of the maximum concentration to minimum concentration was approximately 20 , and the extent of concentration variation together with climate change was smaller than that of t-Al. For these reasons, we suppose that the transport of $\mathrm{Na}$ through the glacial cycle does not correlate with that of $\mathrm{Al}$ because the source of $\mathrm{Na}$ to Dome Fuji, generally the sea and sea ice, is significantly closer than that of the source of $\mathrm{Al}$, continental crust. Thus, Na was supplied to Dome Fuji from both the sea and crust, while the most significant source of $\mathrm{Al}$ is the crust only. The average concentration of t-Na during 5 - $15 \mathrm{kyr}$ was $41.6 \pm 18.1 \mathrm{mg} \cdot \mathrm{kg}^{-1}$, and that during 15 $30 \mathrm{kyr}$ was $115 \pm 43 \mathrm{mg} \cdot \mathrm{kg}^{-1}$; the LGM/HOL ratio was 3 . Although no previous studies have measured t-Na concentration by full-digestion of the ice core, the concentration of the dissolved $\mathrm{Na}$ in the Holocene and LGM in the Dome $\mathrm{C}$ ice core have been reported by Bigler et al. [7]. The LGM/HOL ratio of dissolved Na calculated from their result, 5, was somewhat larger than the ratio for $\mathrm{t}$ $\mathrm{Na}$ obtained in this study. This ratio difference may indicate that the insoluble fraction of $\mathrm{Na}$ in the ice core gained significance in the Holocene. While sea-salt particles are relatively soluble as compared to mineral particles, there is no assurance that anentire sea-salt particle dissolves when the ice core sample melts. In addition, the melted solution of the ice core contained $\mathrm{Na}$, which was originally included as ions in the snow that were dis- 
solved from the particulate matter at the time the ice core melted. Thus, some difficulties persist in the interpretation of the dissolved constituents in the ice cores. Hence, measurements for total concentration of elements by using the full-digestion method provide meaningful data with clear definition for ice core analysis.

The atmospheric fluxes of mineral $\left(F_{\text {mineral }}\right)$ and seasalt $\left(F_{\text {seasalt }}\right)$ aerosols in Dome Fuji can be estimated from the results of total concentrations of $\mathrm{Al}$ and $\mathrm{Na}$. Although $\mathrm{Al}$ is a major constituent in the Earth's crust and occupies approximately $8 \%$ of the crustal substance, it is a trace element detected in seawater at only $0.8 \mathrm{ppb}$. Therefore, it is a suitable assumption that $\mathrm{t}-\mathrm{Al}$ in the aerosol originated entirely from detritus of mineral particles. On the basis of this assumption, $F_{\text {mineral }}$ in Dome Fuji is calculated from the following equation:

$$
F_{\text {mineral }}=[\mathrm{t}-\mathrm{Al}] \times 100 / 8.23 \times R_{\mathrm{d}},
$$

where $[\mathrm{t}-\mathrm{Al}]$ is the concentration of $\mathrm{t}-\mathrm{Al}, 8.23$ is the mean crustal abundance of $\mathrm{Al}$ in percentage [32] and $R_{\mathrm{d}}$ is the snow accumulation rate of the ice sheet in Dome Fuji at a depth of sample, d (Dome Fuji Ice Core Consortium, personal communication).

The flux of sea-salt aerosol, $F_{\text {sea-salt }}$ is similarly obtained by the following equation:

$$
F_{\text {sea-salt }}=[\text { sea-salt-Na }] \times 100 / 1.06 \times R_{\mathrm{d}},
$$

where [sea-salt-Na] is the concentration of $\mathrm{Na}$ of sea-salt origin, and 1.06 is the mean seawater composition of $\mathrm{Na}$ in percentage [33]. While $\mathrm{Na}$ is a major element of seawater, it is also a major component of the crust, occupying $2.36 \%$ [32]. Hence, t-Na in the atmosphere cannot be assumed as a tracer of sea-salt aerosol at a time or place that included an abundant supply of mineral aerosol [34]. It should be restricted that $\mathrm{Na}$ in aerosol is treated as a tracer of sea-salt when the contribution of mineral aerosol can be neglected. Bigler et al. [7] reported that Na of acrustal origin became significant at the high-dust period of a glacial stage in the Dome $\mathrm{C}$ ice core. Therefore, [seasalt-Na] must be used for calculation of $F_{\text {sea-salt }}$. Assuming that $\mathrm{t}-\mathrm{Al}$ in the ice core is of crustal origin, [sea-salt$\mathrm{Na}$ ] can be calculated by the following formula:

$$
[\text { sea-salt-Na }]=[\mathrm{t}-\mathrm{Na}]-(\mathrm{Na} / \mathrm{Al})_{\text {crust }} \times[\mathrm{t}-\mathrm{Al}],
$$

where $[\mathrm{t}-\mathrm{Na}]$ is the concentration of $\mathrm{t}-\mathrm{Na}$ in the core, and $(\mathrm{Na} / \mathrm{Al})_{\text {crust }}$ is the $\mathrm{Na} / \mathrm{Al}$ ratio in the crust, 0.29 [32]. The results of the calculation of [sea-salt-Na] indicate that the percentage of [sea-salt-Na] to [t-Na] was a maximum of $99.3 \%$ and a minimum of $37.5 \%$ (Figure 1). In particular, roughly $60 \%$ of t-Na in the DF1 core was of crustal origin in the maximum case. The average proportion of [sea-salt-Na] to [t-Na] in the Holocene was $91.1 \% \pm 6.7 \%$ and that in the LGM was $74.0 \% \pm 12.1 \%$. These results suggest that most of the $\mathrm{Na}$ transported to Dome Fuji during a warm and low-dust period is considered to be of sea-salt origin; however, a significant amount of $\mathrm{Na}$ was transported to Dome Fuji from a remote continental crust during a cold and high-dust environment in the LGM. The maximum contributions of crustal $\mathrm{Na}$ in the three glacial maximums, recognized in Figure 1, were 62.5\%, $36.9 \%$, and $53.4 \%$, respectively, in order of recent epochs. In ice core analysis, $\mathrm{Na}$ of crustal origin must be considered, particularly in the periods of glacial maximum. Transport of the sea-salt aerosols to inland Antarctica would not significantly vary in the time scale of glacial-interglacial cycle because production of the sea-salt aerosols occurred in the sea and sea ice near the continent. Conversely, deposition of mineral aerosol on the Antarctic ice sheet became significant in glacial maximums at the end of each glacial epoch because 1) the continenttal shelf exposure increased, accompanied by a decrease in sea level; 2) the arid region on the continents expanded in cold and dry climates; and 3) the frequency of dust storms in the continents and the activity of meridional circulation increased.

The average of atmospheric fluxes of mineral and sea-salt aerosol in Dome Fuji during the glacial maximum and interglacial stage of the last three glacial epochs are presented in Table 1. Abbreviations of climatic divisions, IG (interglacial) and GM (glacial maximum), were defined by the range of age mentioned in the table and were numbered in order of younger stages. The divisions IG1, IG2, and IG3 roughly correspond to stages 1, 5e, and 7e, and GM1, GM2, and GM3 roughly correspond to stages $2,6 \mathrm{~b}$, and $8 \mathrm{~d}$ of the Marine Isotope Stage, respectively. The whole mean of each stage of IG and GM is also shown in the table. The average atmospheric fluxes of mineral aerosol in Dome Fuji at GM periods, $14.0-20.2 \mathrm{mg} \cdot \mathrm{m}^{-2} \cdot \mathrm{yr}^{-1}$, were approximately one order of

Table 1. Average atmospheric fluxes of mineral and sea-salt in Dome Fuji, Antarctica, during glacial maximum and interglacial stages of last three glacial cycles.

\begin{tabular}{cccc}
\hline $\begin{array}{c}\text { Climatic } \\
\text { division }\end{array}$ & $\begin{array}{c}\text { Period } \\
\mathrm{Kyr}\end{array}$ & $\begin{array}{c}\text { Mineral flux } \pm 1 \mathrm{~s} \\
\mathrm{mg} \cdot \mathrm{m}^{-2} \cdot \mathrm{yr}^{-1}\end{array}$ & $\begin{array}{c}\text { Sea-salt flux } \pm 1 \mathrm{~s} \\
\mathrm{mg} \cdot \mathrm{m}^{-2} \cdot \mathrm{yr}^{-1}\end{array}$ \\
\hline IG1 & $5-14$ & $4.15 \pm 2.42$ & $112 \pm 54$ \\
$\mathrm{GM} 1$ & $15-30$ & $19.9 \pm 9.9$ & $126 \pm 49$ \\
$\mathrm{IG} 2$ & $120-134$ & $3.22 \pm 1.67$ & $115 \pm 66$ \\
$\mathrm{GM} 2$ & $135-149$ & $14.0 \pm 8.0$ & $133 \pm 55$ \\
$\mathrm{IG} 3$ & $235-249$ & $3.71 \pm 1.03$ & $105 \pm 34$ \\
$\mathrm{GM} 3$ & $265-279$ & $20.2 \pm 10.8$ & $155 \pm 85$ \\
$\mathrm{IG}_{\text {mean }}$ & & $3.77 \pm 2.20$ & $111 \pm 54$ \\
$\mathrm{GM}_{\text {mean }}$ & & $18.6 \pm 10.1$ & $130 \pm 55$ \\
\hline
\end{tabular}

$\mathrm{IG}_{\text {mean }}$ and $\mathrm{GM}_{\text {mean }}$ represent the whole mean for IG and GM periods, respectively. 
magnitude larger than the value at IG periods, $3.22-4.15$ $\mathrm{mg} \cdot \mathrm{m}^{-2} \cdot \mathrm{yr}^{-1}$. These results indicate that the generation and transport of mineral aerosols were activated during periods of glacial maximum. The mineral flux in GM2 was somewhat smaller than that in GM1 and GM3, which may have occurred because interstadials were more frequent within the period of GM2 than those in GM1 and GM3 (Figure 1). The average fluxes of mineral aerosol in the periods of interglacial and glacial maximum were $3.77 \mathrm{mg} \cdot \mathrm{m}^{-2} \cdot \mathrm{yr}^{-1}$ and $18.6 \mathrm{mg} \cdot \mathrm{m}^{-2} \cdot \mathrm{yr}^{-1}$, respectively. The ratios of the mineral flux in GM and that in $\mathrm{IG}$, the $\mathrm{GM} / \mathrm{IG}$ ratio, were $4-5$, and the $\mathrm{GM}_{\text {mean }} / \mathrm{IG}_{\text {mean }}$ ratio was 4.9. Gaspari et al. [10] reported that the LGM/HOL ratio of acid-leachable Fe flux in the Dome $\mathrm{C}$ ice core is 36. Moreover, it was reported that the LGM/ HOL ratio of micro-particle flux in the Vostok ice core is $\sim 15$ [5]. The ratios obtained in this study were smaller than those in previous studies, which used different methods. We consider that the ratios obtained in this study are highly appropriate for explaining differences in mineral aerosol transport between the periods of glacial maximum and interglacial because our results were obtained by a fulldigestion homogenous particulate analysis. As evidence, the LGM/HOL ratios of the atmospheric mineral flux restored from the deep-sea sediment core, 3 - 4 [31,35-37], were comparable to the values obtained in this research. The fluxes of sea-salt show no remarkable differences in IG and GM, and the values of $\mathrm{IG}_{\text {mean }}$ and $\mathrm{GM}_{\text {mean }}$ were $111 \pm 54 \mathrm{mg} \cdot \mathrm{m}^{-2} \cdot \mathrm{yr}^{-1}$ and $130 \pm 55 \mathrm{mg} \cdot \mathrm{m}^{-2} \cdot \mathrm{yr}^{-1}$, respectively. The GM/IG ratios obtained in this study were near unity. This result indicates that although no significant difference was evident in the average sea-salt flux in Dome Fuji between the period of glacial maximum and interglacial, the flux varied widely among data. The results obtained in this study suggest that the variation of mineral flux in Dome Fuji together with climate change was much larger than that of sea-salt flux. Conversely, the variation in sea-salt flux may be affected more by shortterm phenomena than by climate change. To evaluate the relationship between climate change and variability of aerosol flux, the coefficients of variation $(\mathrm{CV})$ of the agemoving average of $F_{\text {mineral }}$ and $F_{\text {sea-salt }}$ in various age intervals were calculated. The CV was obtained by the standard deviation of the age-moving average divided by the average. Age intervals for the moving average were set at 0 - $1 \mathrm{kyr}, 1$ - $5 \mathrm{kyr}, 5$ - $15 \mathrm{kyr}$, and 15 - $25 \mathrm{kyr}$ and subsequently at intervals of $10 \mathrm{kyr}$ until 95 - $105 \mathrm{kyr}$. For example, 271 datasets were obtained by calculation through $340 \mathrm{kyr}$ at an age interval of $0-1 \mathrm{kyr}$. The average CV obtained by calculation in each age interval is shown in Figure 2. The CV of $F_{\text {mineral }}$ increased with age interval. The rate of increase is significant in the range of $0-1 \mathrm{kyr}$ to 5 - $15 \mathrm{kyr}$, which may reflect sudden climate changes. In the age interval of $0-1 \mathrm{kyr}$, the $\mathrm{CV}$ of $F_{\text {mineral }}$ and

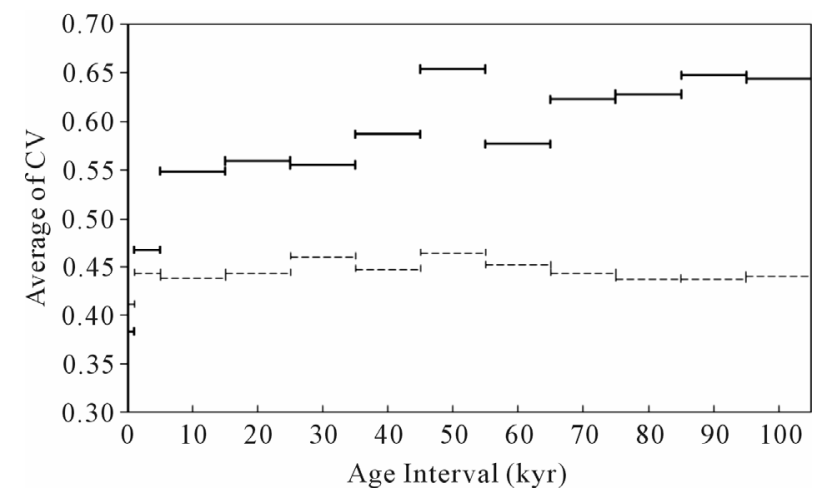

Figure 2. Average of coefficients of variation (CV) of mineral (solid lines) and sea-salt (dashed lines) fluxes to Dome Fuji in various age intervals.

$F_{\text {sea-salt }}$ were 0.38 and 0.41 , respectively, which suggests that the supply of mineral and sea-salt aerosols to the Antarctic ice sheet have nearly the same variation in the 0 1 kyr time interval. The $\mathrm{CV}$ of $F_{\text {mineral }}$ gradually increased from the age interval of 5 - $15 \mathrm{kyr}$ to 95 - $105 \mathrm{kyr}$, while that of $F_{\text {sea-salt }}$ was nearly constant during the entire age interval. These results support the theory that the supply of mineral aerosol was much more varied than that of sea-salt aerosol, which may be attributed to the following points: 1) The variation in mineral aerosol may be much more sensitive to changes in atmospheric circulation than that of sea-salt aerosol because the source of mineral aerosol, continental crust, is significantly far from the Antarctic ice sheet; 2) changes in the surface environment of the continental crust together with climate changes, e.g., area [Remark 1] and dryness, may be more significant than that of the sea surface; and 3) the change in the seasalt flux to the Antarctic ice sheet would not change significantly with the glacial cycle because both open sea and sea ice are significant sources for sea-salt aerosol.

\section{Conclusion}

The profiles of total concentration of $\mathrm{Al}$ and $\mathrm{Na}$ in the Antarctic ice sheet during the past $340 \mathrm{kyr}$ were clarified by full-digestion analysis of the Dome Fuji ice core. The fluxes of mineral and sea-salt aerosol to Dome Fuji were estimated from the total concentration of $\mathrm{Al}$ and $\mathrm{Na}$ in the core. The average aerosol fluxes in the periods of interglacial and glacial maximum were $3.77 \pm 2.20 \mathrm{mg} \cdot \mathrm{m}^{-2} \cdot \mathrm{yr}^{-1}$ and $18.6 \pm 10.1 \mathrm{mg} \cdot \mathrm{m}^{-2} \cdot \mathrm{yr}^{-1}$, respectively, for mineral aerosol and $111 \pm 54 \mathrm{mg} \cdot \mathrm{m}^{-2} \cdot \mathrm{yr}^{-1}$ and $130 \pm 55 \mathrm{mg} \cdot \mathrm{m}^{-2} \cdot \mathrm{yr}^{-1}$, respectively, for sea-salt aerosol. On the basis of the results obtained in this study, we consider the following scenario for the variation in aerosol flux to the Antarctic ice sheet with the glacial cycle: Transport of sea-salt aerosols generated in the sea and sea ice near Antarctica did not vary significantly in the time scale of the glacial-interglacial cycle. Transport of sea-salt aerosol may be affec- 
ted by short-term scale phenomena such as meteorological conditions rather than climate change. In the glacial maximum at the end of each glacial epoch, deposition of mineral aerosol on the Antarctic ice sheet reached amaximum because the exposure of the continental shelf increased, accompanied by a decrease in sea level, the arid region on the continents was expanded by the cold and dry climate, and the frequency of dust storms in the continents and the activity of meridional circulation increased. Further investigation including analysis in high time-resolution and examination of the chemical compositions of particulates in the DF1 core will be performed to clarify the role of atmospheric mineral and sea-salt aerosols in climate change.

\section{Acknowledgments}

The authors are deeply indebted to the Dome Fuji field members of the Japanese Antarctic Research Expedition for collecting the ice core. We would also like to acknowledge the members of the Dome Fuji Ice Core Consortium for fruitful discussions. This study was supported partly by the Grant for Joint Research Program of the National Institute of Polar Research and by the Grant for Joint Research Program of the Institute of Low Temperature Science, Hokkaido University.

\section{REFERENCES}

[1] I. Tegen, A. A. Lacis and I. Fung, "The Influence on Climate Forcing of Mineral Aerosols from Disturbed Soils," Nature, Vol. 380, 1996, pp. 419-422. doi:10.1038/380419a0

[2] S. Solomon, D. Qin, M. Manning, Z. Chen, M. Marquis, K. B. Averyt, M. Tignor and H. L. Miller, "Climate Change 2007: The Physical Science Basis. Contribution of Working Group I to the Fourth Assessment Report of the Intergovernmental Panel on Climate Change," Cambridge University Press, Cambridge, 2007.

[3] J. H. Martin, "Glacial-Interglacial $\mathrm{CO}_{2}$ Change: The Iron Hypothesis," Paleoceanography, Vol. 5, 1990, pp. 1-13. doi:10.1029/PA005i001p00001

[4] T. Oba and T. F. Pedersen, "Paleoclimatic Significance of Eolian Carbonates Supplied to the Japan Sea during the Last Glacial Maximum," Paleoceanography, Vol. 14, 1999, pp. 34-41. doi:10.1029/98PA02507

[5] H. Fischer, M.-L. Siggaard-Andersen, U. Ruth, R. Röthlisberger and E. Wolff, "Glacial/Interglacial Changes in Mineral Dust and Sea-Salt Records in Polar Ice Cores: Sources, Transport, and Deposition," Reviews of Geophysics, Vol. 45, 2007, pp. 1-26. doi:10.1029/2005RG000192

[6] R. Traversi, C. Barbante, V. Gaspari, I. Fattori, O. Largiuni, L. Magaldi and R. Udisti, "Aluminum and Iron Record for the Last $28 \mathrm{kyr}$ Derived from the Antarctic EDC96 Ice Core Using New CFA Methods," Annals of Glaciology, Vol. 32, 2004, pp. 300-306.

\section{doi: $10.3189 / 172756404781814438$}

[7] M. Bigler, R. Röthlisberger, F. Lambert, T. F. Stocker and D. Wagenbach, "Aerosol Deposited in East Antarctica over the Last Glacial Cycle: Detailed Apportionment of Continental and Sea-Salt Contributions," Journal of Geophysical Research, Vol. 111, 2006, Article ID: D08205. doi:10.1029/2005JD006469

[8] G. Ghermandi, R. Cecchi, M. Capotosto and F. Marino, "Elemental Composition Determined by PIXE Analysis of the Insoluble Aerosol Particles in EPICA-Dome C Ice Core Samples Representing the Last 27,000 Years," Geophysical Research Letters, Vol. 30, 2003, pp. 21-76. doi:10.1029/2003GL018169

[9] F. Marino, V. Maggi, B. Delmonte, G. Ghermandi and J. R. Petit, "Elemental Composition (Si, Fe, Ti) of Atmospheric Dust over the Last $220 \mathrm{kyr}$ from the EPICA Ice Core (Dome C, Antarctica)," Annals of Glaciology, Vol. 39, 2004, pp. 110-118. doi:10.3189/172756404781813862

[10] V. Gaspari, C. Barbante, G. Cozzi, P. Cescon, C. F. Boutron, P. Gabrielli, G. Capodaglio, C. Ferrari, J. R. Petit and B. Delmonte, "Atmospheric Iron Fluxes over the Last Deglaciation: Climatic Implications," Geophysical Research Letters, Vol. 33, 2006, Article ID: L03704. doi:10.1029/2005GL024352

[11] R. Losno, J. L. Colin, N. Lebris, G. Bergametti, T. Jickells and B. Lim, "Aluminum Solubility in Rainwater and Molten Snow," Journal of Atmospheric Chemistry, Vol. 17, 1993, pp. 29-43. doi:10.1007/BF00699112

[12] S. Kawakubo and M. Iwatsuki, "Speciation of Iron in Rain Water by Size Fractionation, Acid Decomposition, Acid Extraction and Catalytic Determination," Analytical Sciences, Vol. 16, 2000, pp. 945-949.

doi:10.2116/analsci.16.945

[13] M.-L. Siggaard-Anderse, P. Gabrielli, J. P. Steffensen, T. Strømfeldt, C. Barbante, C. Boutron, H. Fischer and H. Miller, "Soluble and Insoluble Lithium Dust in the EPICA Dome C Ice Core-Implications for Changes of the East Antarctic Dust Provenance during the Recent Glacial-Interglacial Transition," Earth and Planetary Science Letters, Vol. 258, 2007, pp. 32-43. doi:10.1016/j.eps1.2007.03.013

[14] R. H. Rhode, J. A. Baker, M.-A. Millet and N. A. N. Bertler, "Experimental Investigation of the Effects of Mineral Dust on the Reproducibility and Accuracy of Ice Core Trace Element Analyses," Geochemical Geology, Vol. 286, 2011, pp. 207-211. doi:10.1016/j.chemgeo.2011.05.006

[15] Dome-F. Deep Coring Group, "Deep Ice-Core Drilling at Dome Fuji and Glaciological Studies in East Dronning Maud Land, Antarctica," Annals of Glaciology, Vol. 27, 1998, pp. 333-337.

[16] O. Watanabe, J. Jouzel, S. Johnsen, F. Parrenin, H. Shoji and N. Yoshida, "Homogeneous Climate Variability across East Antarctica over the Past Three Glacial Cycles," Nature, Vol. 422, 2003, pp. 509-512. doi:10.1038/nature01525

[17] K. Kawamura, F. Parrenin, L. Lisiecki, R. Uemura, F. Vimeux, J. P. Severinghaus, M. A. Hutterli, T. Nakazawa, S. Aoki, J. Jouzel, M. E. Raymo, K. Matsumoto, H. Na- 
kata, H. Motoyama, S. Fujita, K. Goto-Azuma, Y. Fujii and O. Watanabe, "Northern Hemisphere Forcing of Climatic Cycles in Antarctica over the Past 360,000 Years," Nature, Vol. 448, 2007, pp. 912-916. doi:10.1038/nature 06015

[18] Dome-F. Ice Core Research Group, "Preliminary Investigation of Palaeoclimate Signals Recorded in the Ice Core from Dome Fuji Station, East Dronning Maud Land, Antarctica," Annals of Glaciology, Vol. 27, 1998, pp. 338342.

[19] Y. Fujii, M. Kohno, S. Matoba, H. Motoyama and O. Watanabe, "A $320 \mathrm{~K}$-Year Record of Microparticles in the Dome Fuji, Antarctica Ice Core Measured by Laser-Light Scattering," Memories of National Institute of Polar Research Special Issue, Vol. 57, 2003, pp. 46-62.

[20] Y. Fujii, M. Kohno, H. Motoyama, S. Matoba, O. Watanabe, S. Fujita, N. Azuma, T. Kikuchi, T. Fukuoka and T. Suzuki, "Tephra Layers in the Dome Fuji (Antarctica) Deep Ice Core," Annals of Glaciology, Vol. 29, 1999, pp. 126130. doi:10.3189/172756499781821003

[21] H. Ohno, M. Igarashi and T. Hondoh, "Salt Inclusions in Polar Ice Core: Location and Chemical Form of WaterSoluble Impurities," Earth and Planetary Science Letters, Vol. 232, 2005, pp. 171-178. doi:10.1016/j.epsl.2005.01.001

[22] Y. Iizuka, T. Miyake, M. Hirabayashi, T. Suzuki, S. Matoba, H. Motoyama, Y. Fujii and T. Hondoh, "Constituent Elements of Insoluble and Non-Volatile Particles during the Last Glacial Maximum Exhibited in the Dome Fuji (Antarctica) Ice Core," Annals of Glaciology, Vol. 55, 2009, pp. 552-562. doi:10.3189/002214309788816696

[23] Y. Iizuka, R. Uemura, H. Motoyama, T. Suzuki, T. Miyake, M. Hirabayashi and T. Hondoh, "Sulphate-Climate Coupling over the Past 300,000 Years in Inland Antarctica," Nature, Vol. 490, 2012, pp. 81-84. doi:10.1038/nature11359

[24] T. Suzuki and M. Sensui, "Application of Microwave Acid Digestion Method to the Decomposition of Rock Samples," Analytica Chimca Acta, Vol. 245, 1991, pp. 43-48. doi:10.1016/S0003-2670(00)80199-3

[25] M. De Angelis, N. I. Barkov and V. N. Petrov, "Aerosol Concentrations over the Last Climatic Cycle (160 kyr) from an Antarctic Ice Core," Nature, Vol. 325, 1987, pp. 318-321. doi:10.1038/325318a0

[26] CLIMAP Project Members, "The Surface of the Ice-Age Earth," Science, Vol. 191, 1976, pp. 1131-1144. doi:10.1126/science.191.4232.1131

[27] M. Ram, R. I. Gayley and J. R. Petit, "Insoluble Particles in Antarctic Ice: Background Aerosol Size Distribution and Diatom Concentration," Journal of Geophysical Research, Vol. 93, 1988, pp. 8378-8382.

doi:10.1029/JD093iD07p08378

[28] P. A. Mayewski, L. D. Meeker, S. Whitlow, M. S. Twickler, M. C. Morrison, P. Bloomfield, G. C. Bond, R. B. Alley, A. J. Gow, P. M. Grootes, D. A. Meese, M. Ram, K. C. Taylor and W. Wumkes, "Changes in Atmospheric Circulation and Ocean Ice Cover over the North Atlantic during the Last 41,000 Years," Science, Vol. 263, 1994, pp. 1747-1751. doi:10.1126/science.263.5154.1747

[29] J. P. Steffensen, "The Size Distribution of Microparticles from Selected Segments of the Greenland Ice Core Project Ice Core Representing Different Climatic Periods," Journal of Geophysical Research, Vol. 102, 1997, pp. 26755-26763. doi:10.1029/97JC01490

[30] M. C. Reader, I. Fung and N. McFarlane, "The Mineral Dust Aerosol Cycle during the Last Glacial Maximum," Journal of Geophysical Research, Vol. 104, 1999, pp. 9381-9398. doi:10.1029/1999JD900033

[31] T. Irino and R. Tada, "High-Resolution Reconstruction of Variation in Aeolian Dust (Kosa) Deposition at ODP Site 797, the Japan Sea, during the Last 200 ka," Global and Planetary Change, Vol. 35, 2003, pp. 143-156. doi:10.1016/S0921-8181(02)00135-2

[32] S. R. Taylor, "The Abundance of Chemical Elements in the Continental Crust: A New Table," Geochimicaet Cosmochimica Acta, Vol. 28, 1964, pp. 1273-1285. doi:10.1016/0016-7037(64)90129-2

[33] W. S. Broecker and T.-H. Peng, "Tracers in the Sea," Eldigio Press, Palisades, New York, 1982.

[34] T. Suzuki and S. Tsunogai, "Origin of Calcium in Aerosols over the Western North Pacific," Journal of Atmospheric Chemistry, Vol. 6, 1988, pp. 363-374. doi:10.1007/BF00051597

[35] S. A. Hovan, D. K. Rea, N. G. Pisias and N. J. Shackleton, "A Direct Link between the China Loess and Marine $\mathrm{d}^{18} \mathrm{O}$ Records: Aeolian Flux to the North Pacific," Nature, Vol. 340, 1989, pp. 296-298. doi:10.1038/340296a0

[36] S. C. Clemens and W. L. Prell, "Late Pleistocene Variability of Arabian Sea Summer Monsoon Winds and Continental Aridity: Eolian Records from the Lithogenic Component of Deep-Sea Sediments," Paleoceanography, Vol. 5, 1990, pp. 109-145. doi:10.1029/PA005i002p00109

[37] P. B. deMenocal, W. F. Ruddiman and E. M. Pokras, "Influences of High- and Low-Latitude Processes on African Terrestrial Climate: Pleistocene Eolian Records from Equatorial Atlantic Ocean Drilling Program Site 663," Paleoceanography, Vol. 8, 1993, pp. 209-242. 